Оригинални научни рад

061.1EU:341.98

Maja Stanivuković, Ph.D., Full Professor

Faculty of Law Novi Sad

\title{
Recasting of the Brussels I Regulation and its Impact upon Third Countries, in Particular Serbia ${ }^{1}$
}

\begin{abstract}
The recasting of the Brussels I regulation has been announced by the European Commission in December 2010. The author argues that its impact will be felt in third countries, too. If the Commission proposal is adopted, defendants domiciled in non-EU countries will be amenable to suit in the courts of the Union in civil and commercial matters under the heads of special jurisdiction defined in the EU Regulation. National rules of jurisdiction will no more be applicable. Two new heads of general jurisdiction applicable in case there is no jurisdiction under the Regulation (i.e. when the defendant is domiciled outside the EU and there is no ground of special jurisdiction for EU courts) will be the forum of property and the forum necessitates. A court within the EU will have discretion to stay the proceedings in case of lis pendens before the court of a third country. Judgments from third countries will continue to be recognized pursuant to national rules, including the national rules on indirect jurisdiction. Finally, forum selection clauses in favor of third country courts will most likely be unenforceable in the EU unless the court within the EU would anyway lack jurisdiction (even without the forum selection clause). These rules are only a proposal and they may still be changed. The Commission could make a significant improvement by small interventions in the proposed text, e.g. by giving the rules on exclusive jurisdiction reflexive effect and introducing a specific provision affording effect to prorogation clauses in favor of third country courts.
\end{abstract}

Key words: Brussels I Regulation, international jurisdiction, exequatur, forum selection clauses

${ }^{1}$ Овај рад написан је за потребе пројекта Хармонизација српског и мађарског (домаћег) права са правом Европске уније и прекогранична сарадња. 
The topic of this paper are the proposed amendments of the Brussels I Regulation and their effect upon third countries, such as Serbia. The proposal for amendment was made by the European Commission on 14 December 2010 (the Commission Proposal, or CP). ${ }^{2}$ There are two main projects within this proposal that attract general interest. One is to change the scope of the European jurisdictional rules and the other is to abolish exequatur. There are also some other less comprehensive changes that are worth noting, in particular the effort of the European legislator to enhance effectiveness of forum selection and arbitration clauses. It happens that Serbia is in the process of drafting its first Private International Law Code and replacing the ex-Yugoslav Code after thirty years of application. The legislative reform of EU jurisdictional and exequatur rules will therefore have impact not only in the sphere of future litigation that might concern parties from Serbia, but possibly also in the sphere of shaping of Serbia's future rules of private international law.

\section{The Changing Scope of the Rules on Special Jurisdiction}

On the basis of its enlarged jurisdiction to legislate in the Private International Law field, ${ }^{3}$ the European Union intends to transform its rules on internal conflicts of jurisdiction into rules that also cover international conflicts of jurisdiction. At present the Regulation contains rules for assertion of special jurisdiction over the defendants domiciled in a Member State. If the proposal is adopted, heads of special jurisdiction defined in Sections 2-7, Articles 5-24 of the current Regulation will become universally applicable. They will apply in all cases falling into the scope of application of the Regulation, notwithstanding the defendant's domicile. A defendant domiciled in Serbia will be amenable to suit in a Member State in a contractual dispute if the place of performance of the obligation in question (e.g. payment) is in that State (CP Art. 5(1)). In a sales dispute, jurisdiction over such a defendant will exist in the Member State in which, under the contract, the goods were delivered or should have been delivered (CP Art. 5(1)(a)). In a dispute based on the contract for provision of services, the court of a member country where under the contract, the services were provided or should have been provided, will have jurisdiction (CP Art. $5(1)(b))$. The place where the harmful event occurred or may occur will provide

${ }^{2}$ Proposal for a Regulation of the European Parliament and of The Council on jurisdiction and the recognition and enforcement of judgments in civil and commercial matters $\operatorname{COM}(2010)$ 748 final, dated 14.12. 2010. The Commission analyzed the costs and benefits of the proposed reform in its Impact Assessment which accompanies the Proposal. Commission Staff Working Paper, Impact Assessment SEC(2010) 1547 final.

${ }^{3}$ Article $81(2)$ TFEU provides a basis for adoption of measures aimed at developing judicial cooperation in civil matters having cross-border implications. 
a basis for jurisdiction of a court in the member country in matters relating to delict or quasi-delict (CP Art. 5(2)). Defendants operating through a branch or an establishment in the European Union will have to be prepared to defend a suit arising out of its operations in the courts of the member country in which the branch/establishment is situated (CP Art. 5(5)). The same extension of scope also concerns the protective rules of jurisdiction in disputes arising out of insurance, consumer and employment contracts (Articles 8-21). For example, a Serbian seller of consumer goods that enters into a contract with a consumer domiciled in a member state of the European Union will be exposed to litigation in that member state provided that the contract falls within the scope of the seller's activities directed to that member state or to several states including that member state (CP Art. 15(1)(c)). Similarly, a Serbian employer will be accessible to action filed by an employee in the courts of the member state in which the employee habitually carried out his work (CP Art. 19(1)(a)). Further implication of this is that the a great part of the case law of the EU Court of Justice interpreting the meaning of the jurisdictional provisions (either from the time when they were part of the Brussels Convention, or after they were incorporated in the Regulation no. 44/2001) will become relevant for parties domiciled in a non-EU country.

Compared to the present situation the proposed change seems to be in the interest of a potential Serbian defendant. ${ }^{4}$ Currently, the probability for such a defendant to be sued before the courts of a member state depends on the national rules on international jurisdiction of each member state. This complicates the potential defendant's position and makes it more difficult for him to predict litigation in the EU and account for legal risks. First, national rules of jurisdiction are less accessible than the rules of the European Union. Second, they may be exorbitant as shown by the list contained in Annex I of the Brussels I Regulation which makes it evident that almost every member state is inclined to extend the jurisdiction of its courts beyond internationally recognized limits. Third, and most importantly, judgments based on exorbitant national rules enjoy full faith and credit in other member states - they are fully enforceable under the expedient enforcement regime of the Regulation no. 44/2001. According to the new solution, the national rules of jurisdiction will cease to be applicable to defendants domiciled in a non-member state. ${ }^{5}$ They will remain applicable only

${ }^{4}$ J. Weber, Universal Jurisdiction and Third States in the Reform of the Brussels I Regulation, Max Planck Private Law Research Paper No. 11/7, Electronic copy available at: http://ssrn.com/abstract=1804103, p. 32.

5 "In order to promote the interests of claimants and defendants and promote the proper administration of justice within the Union, the circumstance that the defendant is domiciled in a third State should no longer entail the non-application of certain Union rules on jurisdiction, and there should no longer be any referral to national law", Commission Proposal, Recital 16. 
in disputes that are not covered by this Regulation or by other EU Regulations adopted in the field of private international law. ${ }^{6}$

The rules of special jurisdiction found in Sections 2-7 of the Regulation are reasonable, they are based on a real and substantial connection between the dispute and the country whose court is to exercise jurisdiction, and are thus acceptable to foreign defendants. ${ }^{7}$ If it was only about the universal application of these rules the Commission Proposal could be greeted with enthusiasm. However, at this juncture the European legislator wavers and yields to protectionist sentiments. Instead of totally doing away with exorbitant jurisdiction even in disputes concerning Non-member States, the European Commission includes a new head of jurisdiction in the Proposal to "compensate" the Member States for the "loss" incurred by abolition of national grounds of jurisdiction. ${ }^{8}$ Among the exorbitant heads listed in Annex I, the one least intrusive and most widespread has been chosen to become the new "mildly exorbitant" European head of jurisdiction", applicable to defendants not domiciled in any of the Member States by virtue of the newly proposed Art. 4(2). It is placed in Section 8 of the Proposal under the heading Subsidiary Jurisdiction:

Article 25

Where no court of a Member State has jurisdiction in accordance with Articles 2 to 24, jurisdiction shall lie with the courts of the Member State where property belonging to the defendant is located, provided that and

(a) the value of the property is not disproportionate to the value of the claim;

(b) the dispute has a sufficient connection with the Member State of the court seised.

${ }^{6}$ Such as: Regulation (EC) No. 1346/2000 of 29.5.2000 on insolvency proceedings, O. J. 2000 L 160/1; Regulation (EC) No. 2201/2003 of 27.11.2003 concerning jurisdiction and the recognition and enforcement of judgments in matrimonial matters and the matters of parental responsibility, repealing Regulation (EC) No. 1347/2000, O. J. 2003 L 338/1; Regulation (EC) No. 4/2009 of 18.12.2008 on jurisdiction, applicable law, recognition and enforcement of decisions and cooperation in matters relating to maintenance obligations, O. J. 2009 L 7/1, Regulation (EC) No. 207/2009 of 26.2.2009 on the Community trade mark, O.J. 2009 L 78/1; Council Regulation (EC) No. 6/2002 of 12.12.2001 on Community designs, O. J.2002 L 3/1, and Proposal for a Regulation on jurisdiction, applicable law, recognition and enforcement of decisions and authentic instruments in matters of succession and the creation of a European Certificate of Succession, $\operatorname{COM}(2009) 154$ final of 14.10.2009.

7 "The existing rules on jurisdiction ensure a close link between proceedings to which this Regulation applies and the territory of the Member States which justifies their extension to defendants wherever they are domiciled", Commission Proposal, Recital 17.

${ }_{9}^{8}$ Commission Proposal, Explanatory Memorandum, p. 8

9 "In order to compensate for the abolition of national grounds of jurisdiction, an additional,"mildly exorbitant" forum would be established which grants jurisdiction to the court of the Member State where assets of the defendant are situated." Impact Assessment, p. 24. 
Despite being recognized as exorbitant, jurisdiction based on the location of property within the territory of the court, does not strike the Serbian observer as unjustified. Actually, the same head of jurisdiction currently exists in the exYU Private International Code,$^{10}$ where it was inserted under the influence of Austrian and German law of civil procedure. With two additional conditions added by the European legislator, this head of jurisdiction, that takes into account the prospects for enforcement of the judgment of the court seized of the matter seems to be reasonable enough. The current endorsement by the European Commission will increase its legitimacy and will make it a likely candidate for retention in the new Serbian Private International Law Code as well.

Another "safeguard" provision incorporated in Section 8 of the Commission Proposal is the forum necessitatis, a new head of jurisdiction intended for defendants having domicile outside of the Union. The jurisdiction of this kind exists "on an exceptional basis...if the right to a fair trial or the right to access to justice so requires ":

\section{Article 26}

Where no court of a Member State has jurisdiction under this Regulation, the courts of a Member State may, on an exceptional basis, hear the case if the right to a fair trial or the right to access to justice so requires, in particular:

(a) if proceedings cannot reasonably be brought or conducted or would be impossible in a third State with which the dispute is closely connected; or

(b) if a judgment given on the claim in a third State would not be entitled to recognition and enforcement in the Member State of the court seised under the law of that State and such recognition and enforcement is necessary to ensure that the rights of the claimant are satisfied;

and the dispute has a sufficient connection with the Member State of the court seised.

The draft Introductory Provisions of the new Serbian Private International Code $^{11}$ include a similar rule under the heading "Jurisdiction on an Exceptional Basis":

Article 13

Where this Law does not provide for jurisdiction of a court or other authority in the Republic of Serbia, and the proceedings cannot be brought abroad or it can-

${ }^{10}$ Službeni list SFRJ No. 43 of 23 July 1982 with corrigenda in No. 72/82, as amended in Službeni list SRJ No. 46 of 4 October 1996, and as amended by the Law of Arbitration, Službeni glasnik RS No. 46 of 10 June 2006.

${ }^{11}$ The text of the first 32 articles of the draft was published in B. Bordaš and M. Stanivuković (eds.) The Proceeds of the Novi Sad Faculty of Law from the seventh Private International Law Conference - Enlargement of the European Judicial Area to CEFTA Countries, September 25, 2009, pp. 188-195. After a pause of approximately two years, the Working Group has been continued with its work in March 2011. 
not be reasonably required that the proceedings be brough abroad, jurisdiction lies with the court or other authority of the Republic of Serbia in the place with which the subject-matter has a sufficient connection.

The cited provision of the Serbian Draft draws from Article 3 of the Swiss Private International Law Code. While it corresponds to Art. 26(a) of the Commission Proposal, it fails to cover the case from Art. 26(b) - the situation when a judgment of the foreign court would not be entitled to recognition and enforcement. It is worth considering whether this case should be covered, too. Where does the certainty of a judge deciding upon jurisdiction that a judgment of the foreign court will not be entitled to recognition in his country stem from? It may only stem from a general condition of recognition that applies to that particular country. For example, it may be a priori known that judgments from a certain country will not be recognized for lack of reciprocity, or because its "judiciary cannot be considered to be independent or is riven by corruption." ${ }^{12}$ Other grounds of a of a prior knowledge, such as exclusive jurisdiction of the domestic courts are not applicable because this is per definition the case where "no domestic court has jurisdiction". Although the new Serbian rules on recognition of foreign judgments have not been drafted yet it is not expected that they will include the condition of reciprocity or any other general condition of such nature. Thus, it is hard to imagine instances when the judge deciding on whether to accept jurisdiction based on necessity (i.e. judge having no other ground to base it jurisdiction in the case) will be in the position to know in advance and for certain that a judgment "given on the claim in a third State would not be entitled to recognition and enforcement". For that reason, Art. 26(b) of the Commission Proposal does not seem to be a necessary addition to Article 13 of the Serbian Draft PIL Code.

Notwithstanding the general acceptability of this ground of jurisdiction, one is surprised by protectionist and parochial motives expressed by the Commission in favor of embracing forum necessitatis in its Explanatory memorandum: "... [T] he forum of necessity guarantees the right to a fair trial of EU claimants, which is of particular relevance for EU companies investing in countries with immature legal systems." (emphasis added). A country in which EU companies are investing is bound to wonder whether it belongs to the category of "countries with an immature legal system", and wheter qualification "immature" will be abused to oust its courts of jurisdiction in cases that have a real and substantial connection to its own territory. The Commission should be reminded of the famous sentence of the Supreme Court of the United States pronounced in an era of expanding trade: "We cannot have trade and commerce in world

${ }^{12}$ Impact Assessment, Art. 20. The example given to illustrate this assumption in the Impact Assessment is one of the courts of Saudi Arabia. 
markets and international waters exclusively on our terms, governed by our laws, and resolved in our courts." ${ }^{13}$ The same truth is applicable to worldwide EU investments.

Even before the Commission Proposals, special rules on jurisdiction from Sections 2-7 of the Brussels I Regulation exerted influence on the drafters of these rules in the new Serbian PIL Code. For example, rules of Art. 5(1) and 5(5) were taken into account in drafting the provisions on the jurisdiction of Serbian courts in general contractual disputes; rules of Art. 15-17 were incorporated in simplified form into the provision that will determine jurisdiction in disputes arising out of consumer contracts; the same is true for rules of Art. 1821 related to jurisdiction in disputes over individual contracts on employment. The harmonization is not conducted from a sense of duty but due to common sense which favors a "single-track system". The obligation of Serbia under Art. 72 of the Association and Stabilization Agreement ${ }^{14}$ to approximate its legislation to that of the Community does not encompass the rules contained in regulations, since the idea is that the regulations will become automatically applicable once the membership of the Union is attained, and therefore no transposition is required (or allowed for that matter) ${ }^{15}$. Nevertheless, it is considered more practical to align the national system of Private International Law with the EU system immediately to allow the judges and lawyers to gradually learn and get accustomed to rules that once may become part of their national law .

When the rules of jurisdiction from the Regulation acquire universal scope, they will have an even stronger appeal. There will be practically no other national rules of jurisdiction in the EU member states to consider. The national rules of international jurisdiction in the twenty-seven Member States will be set aside as soon as the Commission Proposal enters into force. It would be unwise to model the Serbian rules after the national rules of international jurisdiction of the EU Member States now, when they are already on the track of becoming obsolete.

\section{Retaining the Unilateral Character of the Rules on Jurisdiction}

Implementation of a universal concept of jurisdiction in the Brussels I Regulation does not go so far as to recognize the reflexive effect of its rules on jurisdiction contained in Arts. 22 and 23. The court of a Member State is not

\footnotetext{
${ }^{13}$ The Bremen v. Zapata Off-Shore Co., 407 U.S. 1, 9 (1972).

${ }^{14}$ Stabilisation and Association Agreement between the European Communities and their Member States of the One Part, and the Republic of Serbia, of the Other Part, 29 April, 2008.

${ }^{15}$ National legislation in terms substantially identical to a Community legislation is not permissible according to the ECJ judgment in Case 93/71 Leonesio v. Ministero Dell'agricoltura e Foresete (Fruit Trees).
} 
obliged to decline jurisdiction if the circumstances of the case and the criteria selected in these provisions would point to exclusive jurisdiction of a court of a Non-Member State. For instance, the fact that the immovable property that is the object of a property (in rem) dispute is situated in Serbia, would not deprive a court of a Member State in which the defendant is domiciled of jurisdiction to entertain that property (in rem) dispute. If the property is situated in another Member State, however, that court would have to decline jurisdiction because location of immovable property makes jurisdiction of that Member State Court exclusive. Likewise, exclusive character of jurisdiction conferred by prorogation that is recognized in Art. 23 of the Brussels Regulation (and Proposal) is reserved for the court or the courts of a Member State. A jurisdiction clause in favor of courts of a third country, may not be effective at all if there is a ground of jurisdiction provided in the Brussels regulation that must be applied by a Member State court. The same is true of protective provisions from Arts 12(1), 16(2), 20(1) protecting the policyholders, insured persons, beneficiaries of insurance, consumers and employees. There is simply no ground on which to base a decision declaring the lack of jurisdiction in such cases if these persons are domiciled in a third country. According to the Commission Proposal, the lack of jurisdiction may be declared by a Member State court only if there is no jurisdiction "under this Regulation":

\section{Examination as to Jurisdiction and Admissibility}

Article 27

Where a court of a Member State is seised of a claim which is principally concerned with a matter over which it has no jurisdiction under this Regulation, it shall declare of its own motion that it has no jurisdiction. (emphasis added)

The duty of the Member State court to accept jurisdiction in an international case whenever there is a ground for jurisdiction under the Regulation has been confirmed by the EU Court of Justice in Owusu. ${ }^{16}$ The English court in this case was barred from application of its national rules on forum non conveniens in favor of a court in Jamaica, because it had jurisdiction under the Bussels Convention, Art. 2. The Court of Justice stated:

46..."the Brussels Convention precludes a court of a Contracting State from declining the jurisdiction conferred on it by Article 2 of that convention on the ground that a court of a non-Contracting State would be a more appropriate forum for the trial of the action..."17

${ }^{16}$ Case C-281/02 Andrew Owusu v N.B. Jackson, trading as 'Villa Holidays Bal-Inn Villas' and Others.

${ }^{17}$ Ibidem, para. 46. 
In an earlier case, the Dutch by the Court to was directed by the court to apply its national law as to effect of a forum selection clause designating a court in a third country:

19 .... Article 17 of the Convention does not apply to clauses designating a court in a third country. A court situated in a Contracting State must, if it is seised notwithstanding such a jurisdiction clause, assess the validity of the clause according to the applicable law, including conflict of laws rules, where it sits (Report by Professor Schlosser on the Convention of 9 October 1978 on the Accession of the Kingdom of Denmark, Ireland and the United Kingdom of Great Britain and Northern Ireland to the Convention on Jurisdiction and the enforcement of judgments in Civil and Commercial matters and to the Protocol on its interpretation by the Court of Justice, OJ 1979 C 59, p. 71, paragraph 176). ${ }^{18}$

The Dutch court in this case was seized on the basis of Art. 5(1) of the Brussels Convention. It is uncertain whether after Owusu, there is still room for application of national law to grant effect to a forum selection clause designating a court in a third country in a case where the court in the EU has jurisdiction pursuant to the Regulation. This uncertainty will rise to unprobability if the Commission Proposal is adopted because it provides that "there should no longer be any referral to national law."19

Generally speaking, the rules on jurisdiction espoused by the Commission Proposal remain entirely unilateral. They are not concerned at all with jurisdiction of third country courts but only with jurisdicton of the national courts within the Union. Once such jurisdiction is established, these rules pay no heed to legitimate interests of third States to reserve certain disputes for jurisdiction of their courts. Since the Regulation rules on recognition and enforcement are applicable only to Member State judgments, its rules of jurisdiction are not relevant for enforcement of Non-Member State judgments either (i.e. the fact that the Non-Member State court has based its jurisdiction on the same ground that would be applied by the recognizing court in the EU will not influence the assessment of indirect jurisdiction in the national recognition proceedings). ${ }^{20}$ Such complete unilateralism is regrettable, having in mind the global influence

${ }^{18}$ Case C-387/98, Coreck Maritime GmbH v Handelsveem BV and Others, para. 19.

${ }^{19}$ Commission Proposal, Recital 16.

${ }^{20} \mathrm{~J}$. Weber thinks that the extension of jurisdictional rules to Non-Member State defendants may collaterally bring about the harmonization of the national rules on indirect jurisdiction: "Although the current Proposal does not tackle the problem of third State judgments, it might bring about a harmonisation of the rules on recognition and enforcement under national law through the backdoor as far as the indirect competence of the third State court is concerned. When recognising a non-Member State judgment, a national legal system may further adhere to national rules. But this will no longer be an attractive solution given the fact that the Member State court assumes its jurisdiction (direct competence) under European law." J. Weber, op.cit., p. 24. 
of the European legislator in the Private International Law sphere. ${ }^{21}$ Especially troubling is the fact that the forum selection clauses providing exlusive jurisdiction of the courts of third countries might not be enforceable before the courts of the Member States.

Nevertheless, there is one limited exception from this general rule. It concerns the case when the proceedings in relation to the same cause of action and between the same parties are pending before the courts of a third State at a time when a court in a Member State is seised. The new rule on lis pendens set forth in Art. 34 of the Commision Proposal introduces a discretionary right for a court of the Member State to stay its proceedings in favor of a third country court provided three conditions are fulfilled: the court of the third State was seised first in time, it may be expected that within reasonable time this court will render a judgment capable of recognition and enforcement, and the court is satisfied that the stay is necessary for the proper administration of justice (Art. 34(1)). If over time the perception on the fulfillment of the second and the third condition (reasonable time and proper administration of justice) changes in the eyes of the judge that granted the stay, he may discharge the stay (Art. 34 (3)). It is specified that the party who has seised the court in the Member State will not lose the benefit of interruption of limitation periods during the period of the stay (Art. 34(2)). After the third State court renders a judgment that is capable of recognition and enforcement in that Member State, the court of the Member State that was second seised will dismiss the case. Clearly, the respect for the litigation pending in a third country such as Serbia depends primarily on the judge's discretion. There are many conditions to be met for the stay, the most important being the enforceability of the third country judgments in the particular EU Member State. Still, this novelty represents an improvement in comparison to the previous situation that completely relegated this issue to national law of member states. The caution and reserve with which the European legislator treats the effect of earlier litigation in a foreign country is a warning signal indicating that the proposed rule on lis pendens in the draft of the Serbian PIL Code (Art. 24) ${ }^{22}$ should perhaps be reconsidered in the light of the lis pendens rule drafted by the Commission.

${ }^{21}$ J.Weber, op.cit. p. 9.

${ }^{22}$ Draft Serbian PIL Code, Article 24:

1) The court of the Republic of Serbia shall stay the proceedings at the request of a party if a dispute is pending before a foreign court in the same legal matter and between the same parties, provided:

1. that the proceedings were first instituted before a foreign court in the respective dispute;

2. that the court of the Republic of Serbia does not have exclusive jurisdiction for that legal matter. 
The fact that the new rule on stay of proceedings in favor of a third country court has been proposed, however limited it is, shows that there is room for multilateralism in the Brussels I Regulation regime. Precedence may be given to courts of a third country if they were the first to proceed in a case. The ground of jursidiction on which they proceeded will be examined in the framework of the national rules on recognition of foreign judgments. The readiness to recognize foreign jurisdiction based on the ground which is acceptable according to national standards makes it even more difficult to understand why the rules on exclusive jurisdiction, established in the Regulation, were not bilateralized, i.e. why Article 22-24 could not be framed in univeral terms, so that the courts of a "State" rather than the courts of a "Member State" are referred to as having exclusive jurisdiction in the designated circumstances. Furthermore, the Commission could ensure the effectiveness of forum selection clauses in favor of third countries by a simple intervention in article 23 of the Proposal - i.e. by replacing the words "Member State" with the word State":

If the parties have agreed that a court or the courts of a Member State are to have jurisdiction to settle any disputes which have arisen or which may arise in connection with a particular legal relationship, that court or those courts shall have jurisdiction, unless the agreement is null and void as to its substance under the law of that Member State.

\section{Abolition of Exequatur - (but not for Third Country Judgments)}

Important part of the proposal is the abolition of the exequatur procedure for all judgments covered by the Regulation except for judgments in defamation and compensatory collective redress cases. ${ }^{23}$ Judgments from other Member States will lose the status of "foreign judgments" as clearly signalled by deletion of the word "foreign" from Arts. 45, 48 and 49. They will be directly enforceable in other Member States without the need for declaration of either recognition or enforceability. ${ }^{24}$ Even the translation of the judgment will not be necessary, unless its enforcement is challenged. ${ }^{25}$ Although the exequatur will be

2) The moment of initiating the proceedings is governed by the law of country whose court has been seized of the proceedings. Serbia.

3) The identity of the dispute and of the parties is governed by the law of the Republic of

4) The court of the Republic of Serbia shall at the request of a party continue the proceedings that were stayed if the foreign court declared the lack of jurisdiction or if the foreign judgment is not recognized.

${ }^{23}$ The Commission Proposal, Explanatory Memorandum, p. 6.

${ }^{24}$ The Commission Proposal, Art. 38, the fist one in Chapter III, Section one, Subsection one entitled: "Abolition of Exequatur".

${ }^{25}$ The Commission Proposal, Art. 42(4). 
abolished, the conditions for enforcement that are currently required under Article 34 of the Brussels I Regulation will not wholly dissapear. They will simply be redirected to other procedures. A review procedure that may be applied for in the country of origin by the defendant is envisaged in Art. 45 of the Commission Proposal for cases when the judgment was rendered in default of appearance (current Art. 34(2) of the Brussels I Regulation), while the res judicata defence (Current Arts. 34(3) and 34(4) of the Brussels I Regulation) will remain available as a ground for refusal in the enforcement procedure (Art. 43 of the Commission Proposal). In addition, the defendant will be in the position to challenge the automatic recognition and enforcement of a judgment of another Member State (Commission Proposal, Art 46) by initiating a special procedure for refusal of recognition or enforcement in the country of recognition/enforcement "where such recognition or enforcement would not be permitted by the fundamental principles underlying the right to a fair trial". The burden of costs and time required to successfully resist enforcement will thus be reversed and transferred from the judgment creditor to the judgment debtor. All in all, only the public policy (ordre public) exception will be obliterated and will no longer be available to the parties opposing recognition.

The reasons for abolishing exequatur cited by the Commission in the Explanatory Report are the following: "The procedure for recognition and enforcement of a judgment in another Member State ("exequatur") remains an obstacle to the free circulation of judgments which entails unnecessary costs and delays for the parties involved and deters companies and citizens from making full use of the internal market." ${ }^{26}$ This move has not been uncontroversial, ${ }^{27}$ and it is still to be seen whether the European legislators will accept the proposal in the form it is presented now.

The Proposal does not spell it out, but the Impact Assessment does: the liberalization of recognition will not benefit the third country judgments. ${ }^{28}$ This policy was considered by Commission staff and discarded because the Member States are "very reluctant as to a harmonisation of the regime of recognition and enforcement." They prefer the issue to remain governed by national law or international conventions. Since it is not likely that a worldwide multilateral con-

${ }^{26}$ The Commission Proposal, p. 3.

${ }^{27}$ G. Cuniberti, I. Rueda, Abolition of Exequatur Addressing the Commission's Concerns, Luxembourg, http://ssrn.com/abstract=1691001, pp. 6 and 14: "...the contributions to the relevant Green Paper appeared to favour the adoption of a procedure and of grounds for non recognition of foreign judgements similar to those of the Brussels I Regulation, rather than the mere abolition of exequatur supported by the European Council in the Stockholm Programme." and "...the vast majority of scholars who have written on the topic have argued against the abolition of exequatur."

${ }^{28}$ Impact Assessment, pp. 24-25. 
vention could be negotiated in the foreseeable future, considering the fiasco of the 1999 Judgments Convention Project of the Hague Conference on Private International Law, the issue is firmly relegated to the realm of national law and/or regional and bilateral conventions.

For European "third countries" such as Serbia that are highly integrated in this region with trade and population ties, but will remain politically excluded from the Union for an undetermined period of time, the cited conclusion of the European Commission is important for several reasons. First, the reality is that recognition and enforcement of civil and commercial law judgments of the Serbian courts in the European Union will remain subjected to legal regimes of 27 national States. Even when recognized in one of these States, the judgment will not enjoy the benefit of full faith and credit in other Member States. It will have to pass through the recognition and enforcement procedure in every particular Member State where it needs to take effect. As the most recent national legislation shows, the national legal regimes are not likely to abolish exequatur. $^{29}$ Therefore, a beneficiary of a Serbian judgment wishing to enforce it in the EU will thus have to endure additional costs and loss of time entailed by exequatur. This will be even more burdensome because of the existing differences in the general standard of living and the relative costs of proceedings in Serbia and in most EU countries. Considering that the European legislator is aware of the drawbacks of the exequatur procedure and that it has legislative competence in the external relations field to enter into a convention regulating this subject matter, it would be worth trying to negotiate a bilateral convention with the EU on recognition and enforcement of judgments. The paramount question that will affect the success of such an endeavour is whether Serbia can inspire trust of the European Commission and the Member Staes as to the quality of its judiciary and the procedures applied by it to render judgments. Another significant factor will be the relative importance of this issue for the relevant parties, i.e. whether Serbia can bring the European Commission to negotiating table concerning an agreement which would be of considerable importance for Serbia, but of much less importance for the European Union. Possibly, taking the latter factor into account, Serbia should pursue a strategy of joining the Lugano Convention. Such a multilateral solution would be far superior to a bilateral convention. Participation in the Lugano system would secure a minimum of procedural fairness and establish recoprocity with more than 30 European states. ${ }^{30}$ An

${ }^{29}$ See for example. the Private International Code of Belgium (2004), Arts. 22-30 and the Private International Law Code of Bulgaria (2005), Arts. 117-124.

${ }^{30}$ D. Martiny, The Idea Underlying the Lugano Convention - Experience in its Application and Reform, in B. Bordaš, M. Stanivuković (eds), Collected Papers from the VIIth Private International Law Conference - Enlargement of the European Judicial Area to CEFTA Countries, September 25, 2009, Novi Sad Faculty of Law, Novi Sad, 2010, p. 28. 
alternative strategy would be to follow a regional approach and seek an agreement with the countries of the CEFTA region on mutual recognition and enforcement of judgments on a path similar to EFTA countries and the Lugano Convention, ${ }^{31}$ hoping that this new CEFTA convention would be important enough to attract the attention of the European Commission and prompt it to become a contracting party. However, this initiative would fail if only one of the CEFTA member states could not justify the mutual trust required for automatic enforcement of its civil and commercial law judgments in the entire "Area of freedom, justice and security". The problem of effectiveness of forum selection clauses could be resolved by accession to the Hague Convention on the Choice of Court (2005), if the Convention is ratified by the EU. ${ }^{32}$

Second thing of importance is that the policy of the European Union towards third country judgments is a strong signal on the existence of risks in excessive liberalization of rules on enforcement and recognition of foriegn judgments. If the entity such as the European Union, possessing impressive legal and economic resources and capacities, evaluates that exequatur is still needed in relation to the world as a way of protection of fundamental rights of parties and of fundamental values of the national legal systems, in particular through the public policy defense, then exequatur is needed in small countries like Serbia as well. When the rules on recognition and enforcement of judgments in the civil and commercial law area come to the agenda of the working group for reform of the PIL Code it should look for the drafting model for these rules beyond the Proposal for Recasting of the Brussels I Regulation, because the rules from the Proposal are inteded only for intra-Union enforcement of judgments. This is emphasised because there is a tendency among domestic PIL experts to rely on European rules even if they are not entirely suitable for domestic circumstances. For example, the reform of the rules on enforcement of foreign judgments undertaken in the Serbian Code on Enforcement of 2004, was inspired by the already liberal rules on recognition and enforcement of the Brussels I Regulation of 2001. Making a step further and adopting a no-exequatur approach in the new PIL code could result in total lack of remedies for situations involving foreign judgments involving infringement of human rights or exorbitant grounds of jurisdiction, or substantive law notions that are entirely alien to Serbian concepts of justice and fairness. Therefore, members of the Serbian working group for PIL reform would do best to look for inspiration for

${ }^{31}$ For a more comprehensive discussion of advantages and disadvantages of this approach see B. Bordaš, M. Stanivuković (eds), Collected Papers from the VIIth Private International Law Conference - Enlargement of the European Judicial Area to CEFTA Countries, September 25, 2009, Novi Sad Faculty of Law, Novi Sad, 2010.

${ }^{32}$ EU signed the Convention in April 2009. 
domestic rules on recognition and enforcement in the newest national laws of the EU Member States, such as Belgium and Bulgaria, as well as in law of other countries of the world that have developped sound PIL rules in this area.

\section{Effect of Forum Selection}

As part of the package to improve access to justice, the Commisson Proposal carries a new duty for the courts spelled out in Art. 24(2) to inform the defendant in the document instituting the proccedings of his right to contest the jurisdiction of the court and on the consequences of entering an appearance without contesting the court's jurisdiction. Before assuming its jurisdiction on the basis of implied consent, the court has to ensure that such information was provided to the defendant.

The utility of this provision is self-explanatory. A foreign defendant receiving an action with summons either in his mailbox or through diplomatic channels, will often hesitate on the right course of action. Will his appearance in the court to which he is summoned be automatically treated as implied consent to jurisdiction and thereby diminish his chances to resist the subsequent enforcement of the judgment? On the other hand, if he does not appear, will this result in a default judgment that might be enforceable if it is proven that the he had a proper notice of the action but failed to defend his case? ${ }^{33}$ Provision of adequate information in the first summons will dispel these doubts and make it easier for the defendant to choose the procedural strategy to follow. The insertion of a similar provision into Article 17 of the Serbian PIL Code is therefore highly recommended. ${ }^{34}$

Primacy of forum selection over all other grounds of jurisdiction has been reinforced by two new provisions that are in a way similar, although they figure in different sections of the Commission Proposal. The first concerns the effect of prorogation clauses, and the second the effect of arbitration clauses upon jurisdiction of the courts of member states under the Regulation. Both rely on solutions derogating from the classical lis pendens rules based on temporal priority. Both are also a reaction to cases that went before the Court of Justice of

${ }^{33}$ For a striking example of this see the facts of Beals v. Saldanha, a case before the Canadian Supreme Court described in A.M. Sears, Beals v. Saldanha: The international Implications of Morguard Made Claer, Saskatchewan Law Review, Vol. 68, 2005, p. 223.

${ }^{34}$ Draft Serbian PIL Code, Article 17 (Implied consent of the defendant to jurisdiction): 1. When jurisdiction of a court of the Republic of Serbia depends on the consent of the defendant to have that court adjudicate the matter, it is considered that the defendant consented to jurisdiction if: a) he failed to contest jurisdiction in his answer to the claim or objection to the payment order; or b) he entered into discussion [of the subject-matter of the dispute] at the preparatory hearing, of if preparatory hearing was not held, at the first hearing of the merits, without fist contesting jurisdiction; or c) he filed a counterclaim. 
the European Union, and their ultimate effect will be to reverse the outcomes of the Court's rulings in future cases of that kind.

When the parties have designated a court or courts of a particular Member State to resolve their dispute, the court of their choice has priority pursuant to the proposal regardless of whether it is first or second seised. Even if it was first seised the court of a Member State has to stay proceedings to allow the chosen court to accept or decline jurisdiction. This is provided in Art. 32(2) of the Commission Proposal. The explanation is that "this modification will increase the effectiveness of choice of court agreements and eliminate the incentives for abusive litigation in non-competent courts." ${ }^{35}$ These "abusive litigation tactics" called "Italian torpedo" are described in more detail in the Impact Assessment. ${ }^{36}$ The prototype of such action are the facts of the case Gasser that was the object of a preliminary reference to the Court of Justice of the EU. An Austrian company concluded a sales contract with an Italian company as the buyer. The invoices sent by the seller and regularly paid for by the buyer contained forum selection clauses in which the parties agreed to bring any disputes under the contract before the courts in Dornbirn, Austria. Eventually however, the buyer defaulted on payment. Before the seller could bring proceedings in Dornbirn, the buyer initiated an action before his national court in Rome seeking declaration that the contract had been terminated and a negative declaration that it had not failed to perform the contract. The Austrian court had to stay the proceedings as the court second seised and the Italian court took more than a year to decide on its own jurisdiction. In the preliminary ruling the Court of Justice held that the provision of the Brussels Convention on lis pendens obliges the court second seised to stay the proceedings until the court first seised has declared that it has no jurisdiction even when the courts second seised would have jurisdiction under a prorogation clause. This rule may not be derogated from even if the duration of the proceedings before the court first seised is excessively long. ${ }^{37}$

In order to mend the negative consequences of the strict application of the temporal priority principle upon the effectiveness of forum selection clauses the Commission is now embracing the views expressed in the written observations of United Kingdom which it successfully opposed in the Gasser proceedings. In addition, the collateral benefit of Gasser is that the Commission proposal sets a general time-limit for rendering a decision on jurisdiction by the court first seised. This court has to "establish its jurisdiction within six months except where exceptional circumstances make this impossible." Considerable pressure

\footnotetext{
${ }^{35}$ The Commission Proposal, pp. 8-9.

${ }^{36}$ Impact Assessment, pp. 28-29.

${ }^{37}$ Case C-116/02 Erich Gasser GmbH v MISAT Srl, operative part of the judgment.
} 
is put on the court first seised to act efficiently, because any other court seised of the dispute may request information "on the date on which it was seised and of whether it has established jurisdiction over the dispute or, failing that, of the estimated time for establishing jurisdiction." The duty of the court first seised to stay the proceedings to allow the chosen court to accept or decline jurisdiction, as well as the duty decide on jurisdiction within a six-month period, do not extend to cases when the court second seised is in the third country. In fact in such cases, it is questionable whether the member state court, competent under the rules of the Regulation, can uphold the choice of forum clauses in favor of a third country court at all, as was explained above.

A similar mechanism is applied to enhance the effectiveness of arbitration agreements in Art. 29(4) of the Commission Proposal. ${ }^{38}$ This amendment was prompted by another "Italian torpedo action" discussed before the Court of Justice of the EU in the West Tankers case. ${ }^{39}$ The facts of the case will be briefly outlined to explain the motivation of the Commission. After a collision of a ship with a jetty in Italy, the charterer of the ship collected from its insurers Alianz and Generali up to the limit of his insurance cover, and for the excess commenced arbitration proceedings in London against the owner of the ship (West Tankers) pursuant to an arbitration clause contained in the charterparty. Having paid compensation to the charterer under the insurance policies Alianz and Generali brought proceedings against the owner of the ship before the court in Siracusa, Italy in order to recover the sums they have paid. Thereupon, West Tankers brought the proceedings before the English court seeking declaration that the dispute between the parties should be settled by arbitration and sought an anti-suit injunction restraining Allianz and Generali from pursuing the litigation before the court in Siracusa, and requiring them to discontinue this litigation in favor of the arbitration. On a reference from the English Court, the Court of Justice of the EU ruled that it is incompatible with the Regulation to restrain a person from commencing or continuing proceedings before the courts of another Member State on the ground that such proceedings would be contrary to an arbitration agreement. ${ }^{40}$ The use of anti-suit injunctions remains allowed, however, if the proceedings are brought before the courts of a Non-member State.

The new rule that is proposed by the Commission in Art. 29(4) gives priority jurisdiction to the arbitral tribunal and to the court at the seat of the arbitra-

\footnotetext{
${ }^{38}$ M. Illmer, Brussels I and Arbitration Revisited - The European Commission's Proposal $\operatorname{COM}(2010) 748$ finalhttp://ssrn.com/abstract=1804079, p. 14.

${ }^{39}$ Case C-185/07 Allianz SpA, formerly Riunione Adriatica di Sicurtà SpA, Generali Assicurazioni Generali SpA, vWest Tankers Inc.

${ }^{40}$ Ibidem, operative part of the judgment.
} 
tion to decide on the validity of the arbitration agreement, notwithstanding the time when they are seised. However, the rule applies only where the agreed or designated seat of arbitration is in a Member State. If that is the case, the court of another Member State whose jurisdiction is contested on the basis of an arbitration agreement must stay the proceedings as soon as the court of the seat of arbitration or the arbitral tribunal have been seised of proceedings to determine the existence, validity or effects of that arbitration agreement, whether as their main object or as an incidental question. In effect, once it is seised of the action the court of the seat of the arbitration (if the seat is in the Member State) acquires a kind of exclusive jurisdiction within the European Union to decide upon the existence, validity and effects of the relevant arbitration agreement. ${ }^{41}$ The same is true in case the action is commenced before the arbitral tribunal. Once the validity or effect of the arbitration agreement are established, the court of the Member State whose jurisdiction was contested on the basis of that arbitration agreement will have to decline jurisdiction.

When the seat of arbitration is in a Non-member State the court first seised is not bound by the proposed rules of the Regulation to give any deference to courts of that state or to the arbitral tribunal even if they have been seised. The Member State court is free to determine the validity of the arbitration agreement pursuant to its own national law on arbitration and to exercise jurisdiction under the Regulation if it determines that the arbitral agreement is invalid or inoperative. As explained by one author, the courts of the seat of arbitration that are located outside of the EU do not deserve the same degree of trust as the courts inside the EU. ${ }^{42}$

\section{Conclusion}

The impact of recasting of the Brussels I regulation announced in December 2010 will be felt in third countries as well. The defendants domiciled in non-EU countries will be amenable to suit in the courts of the Union in civil and commercial matters under the heads of special jurisdiction defined in the EU Regulation. National rules of jurisdiction will no more be applicable. Two new heads of general jurisdiction applicable in case there is no jurisdiction under the Regulation (i.e. when the defendant is domiciled outside the EU and there is no ground of special jurisdiction for EU courts) will be the forum of property and the forum necessitates. A court within the EU will have discretion to stay the

${ }^{41}$ On the criticism of this solution as contrary to the New York Convention on Recognition and Enforcement of Foreign Arbitral Awards (1958) see V,. Lazić, „The amendment to the arbitration exception suggested in the Commission's Proposal: the reasons as to why it should not be accepted" forthcoming.

${ }^{42}$ M. Illmer, op.cit., p. 15. 
proceedings in case of lis pendens before the court of a third country. Judgments from third countries will continue to be recognized pursuant to national rules, including the national rules on indirect jurisdiction. Finally, forum selection clauses in favor of third country courts will most likely be unenforceable in the EU unless the court within the EU would anyway lack jurisdiction (even without the forum selection clause). These rules are only a proposal and they may still be changed. The Commission could make a significant improvement by small interventions in the proposed text, e.g. by giving the rules on exclusive jurisdiction reflexive effect and introducing a specific provision affording effect to prorogation clauses in favor of third country courts. 
Др Маја Сйанивуковић, редовни йрофесор

Правної факулиетей у Новом Саду

\section{ИЗМЕНЕ ПРВЕ БРИСЕЛСКЕ УРЕДБЕ И ЊИХОВ УТИЦАЈ НА ДРЖАВЕ КОЈЕ НИСУ ЧЛАНИЦЕ УНИЈЕ С ПОСЕБНИМ ОСВРТОМ НА СРБИЈУ}

\section{Сажейик}

Европска комисија је у децембру 2010. године најавила значајне промене Прве бриселске уредбе о надлежности и признању и извршењу одлука (Уредба 44/2001). У раду су размотрене оне новине које се односе пре свега на државе изван Уније. Промене се односе на ширење поља примене одредаба о надлежности на тужене који имају пребивалиште изван Уније, на увођење нових основа надлежности и на стварање правног основа да се уважи ранија литиспенденције пред судом државе која није чланица ЕУ. У погледу признања дејства пророгационом споразуму којим је уговорена надлежност суда државе која није чланица Уније, Уредба не предвића могућност оглашавања суда државе чланице ненадлежним у корист изабраног суда. Исто тако ни основи искључиве надлежности успостављени у уредби не важе ако би се искључиво надлежни суд налазио у некој држави нечланици. Норме о надлежности из уредбе имају и даље у потпуности једнострани карактер. Када је у питању признање одлука планира се укидање поступка егзекватуре уз примену механизма минималног (веома ограниченог) поступка провере одлуке из друге државе уговорнице. Непризнавање услед очигледне супротности јавном поретку више неће бити могуће. Правила регулативе о признању и извршењу пресуда и даље се односе само на пресуде из држава чланица ЕУ. Европска унија сматра да је признање страних судских одлука које долазе из тзв. трећих држава могуће остварити само споразумевањем на мултилатералном нивоу. Одлуке трећих држава признају се по правилима националних међународних приватних права. У раду се разматрају и опције које стоје на располагању државама ван Уније као што је Србија да би обезбедиле признање сопствених одлука на територији ЕУ, као и подобност нових правила уредбе да послуже као модел за састављање одредаба новог Закона о међународном приватном праву Србије.

Кључне речи: Прва бриселска регулатива (Регулатива Брисел I), међународна надлежност, егзекватура, пророгациона клаузула 